\title{
Risk Management of Financial Instruments in Islamic Banks: An Overview
}

\author{
Abderrahmane Sakouili*, Razane Chroqui*
}

Received: 29.04 .2018

Accepted: 20.12.2018

DOI: $10.25272 /$ ijisef.419518

Type: Research Article

\begin{abstract}
Risk management plays a major role in the success and survival of various financial institutions around the world. Islamic Financial institutions not being the exception, on the contrary, given the authenticity of their modus operandi and the nature of their financial products, are obliged to use more credible and rigorous risk management systems. A thorough review of the Islamic economy literature based on books, research articles, monographs and reports, was conducted to prepare this study. The main objective is to define and explain the risk management tools (Urboun, Hamish al- Jiddiyah, Khiyarat, Rahn, etc.) used by Islamic financial institutions in financing instruments (Mourabaha, Ijarah, Salam, etc.), in order to unveil their nature and specificity. Which enabled the creation of a summary table presenting the Risk management tools, the products in which they are used and the risks for which they are used.
\end{abstract}

Keywords: Islamic financial institutions, Risk management tools, Financing instruments

Jel Codes: G20,P40,P47

\footnotetext{
* PhD student at the High School of Technology of Berrechid, University Hassan the 1st Settat, Morocco, LAMSAD, a.sakouili@uhp.ac.ma, ORCID: https://orcid.org/0000-0003-3657-9889

${ }^{* *}$ Professor at the High School of Technology of Berrechid, University Hassan the 1st Settat, Morocco, LAMSAD, chroqui@yahoo.fr, ORCID: https://orcid.org/0000-0002-3836-2416
} 


\section{Introduction}

Since its advent, Islamic Finance has been steadily gaining more space and importance in the world's economic sphere. Indeed, it has become a very influential element in the international financial system through the opening of several financial institutions across the globe, including non-Muslim countries, as well as by the huge number of publications and research that has been reserved for it and especially by its contributions in the resolution of various problems encountered by conventional banks (Masiukiewicz (2017), Nestorovic (2013)).

In 2016, according to the Stability Report of the Islamic Financial Services Board (IFSB), the majority of the jurisdictions in which Islamic financial institutions (IFI) operate have recorded reasonable growth rates in assets, financing, and in deposits. The same report also shows that the market shares of Islamic banks have increased in 18 jurisdictions and have remained the same or have decreased marginally in 13 others.

All this evince a growing acceptance and integration of Islamic Finance in jurisdictions with dual financial system. Yet, this revolution driven by the contributions of the IFIs does not go without confronting a great deal of problems such as risk management. Actually, it results on one hand from the constant changes in the economic environment and in the financial products presented by these institutions. On the other hand, it results from the fast evolution of the global financial regulation (Habib \& Khan, 2001).

It is undeniable that the risk incurred by banks has increased in recent years; it is inherent and inevitable to the banking sector. Wilson (2005) explains that banks have to take risks in order to generate returns, which generally when they are higher, they cause greater risks. However, the risks faced by IFI differ in some aspects from those faced by conventional banks. Rosly and Zaini (2008) as well as Hassan and Dicle (2005) argue that the nature of the risk that Islamic banks are exposed to is unique and varies according to the financial instruments used by these banks, to the people they hire to manage their activities, and to the degree of their transparency.

In order to protect themselves from these different risks (counterparty risk, market risk, liquidity risk ...), IFI use several risk management tools consistent with the guidelines of Sharia (Quran and Sunnah). Islam, through the Quran, the Sunnah, and the conduct of Muslims in their business transactions during the time of the Prophet (peace be upon him), has imposed a system that operates in light of certain ethical norms and values to govern all the transactions involving different economic agents. We are going to try to highlight the use thereof as tools of risk management by IFI.

This paper presents itself as an attempt, mainly intended to provide an overview of these tools namely: Hamish al-jiddiyah, Urboun, Al-Rahn, Al-kafala, Al-Khiyarat, al-Ta'wid and Gharamah. We will first, try to present the definition of each tool, to explain how it works, in order to finally show the purpose of its use in the financing products (Murabaha, Ijarah, Salam, Istisna' and Qard Hassan) used by IFI. 
Our choice to focus the research on financing activities is motivated by the fact that these activities are the main source to the majority of the IFI income. The General Council for Islamic Banks and Financial Institutions (CIBAFI), responsible for collecting and disseminating data on these institutions around the world, shows in its report that financing activities represent more than $70 \%$ of the total assets of all Islamic banks of the Gulf Cooperation Council (GCC) while investment activities represent about $11 \%$ of total assets. Furthermore, Archer and Rifaat (2013) point out that Murabaha and other sales-based facilities (in particular Istisna' and Salam) along with lease-based facilities (such as Ijarah) dominate the asset side of Islamic banks ranging from $80 \%$ to $100 \%$ of total facilities.

Given these points, we have thought that it would be most interesting and effective to focus our study on these financial products.

\section{Hamish Al-Jiddiyah}

Hamish al-Jiddiyah is a refundable amount of money retained by the bank before establishing a contract, as a protection from counterparty risk. Its purpose is to limit the extent of losses and damages suffered by the bank in case the customer does not fulfil his obligations; more precisely, it reflects his firm intention (El Tiby, 2011). As mentioned in the definition, it is totally refunded to the customer only if the bank does not suffer any losses, the overall amount rightfully belongs to him. Otherwise, if the sum of those losses is not equal to the entire amount of Hamish al-jiddiyah, only the rest will be then refunded (Ayub, 2007).

Hamish al-Jiddiyah can be used in different Islamic financing products, namely Ijarah and Murabaha. In an Ijarah or a Murabaha contract, the IFI may require, prior to the execution of the contract, that the beneficiary deposits a sum of money as security to ensure the compensation of actual losses incurred in the event of an unfulfilled promise (Bank Negara Malaysia (BNM), 2014). For this type of contracts, Hamish al-Jiddiyah is used to neutralize the counterparty risk and the risks it creates specifically market risk, the risk of increased storage costs, and the risk of losses as a result of property damage.

By way of illustration, if the leaseholder (Ijarah) or the buyer (Mourabaha) refuses to select the asset purchased by the bank, without being able to explain adequately the reasons for his refusal, the bank is forced to choose between two options: selling the asset on the market or finding another customer. (Wahyudi \& al, 2015). If the bank, by selling or renting the asset to another person at a price lower than the one initially agreed upon, suffers any losses, it will be compensated using some or all of the guarantee deposit (Hamish al-jiddiyah) previously retained (Kureshi \& al, 2015).

Moreover, the bank is not usually the natural owner of the asset in these contracts but buys it at the reception of a request for the client. If it is obliged to incur additional costs such as storage, insurance or even damage (naturally perishable goods) by keeping the asset in its property, the losses suffered will be immediately also covered by Hamish al-Jiddiyah (Archer \& Rifaat, 2013). 


\section{Urboun}

It is explained by Imam Malik as : "It's when a person buys a slave or rents an animal and tells the seller or owner of the animal: " I will give you a dinar or a dirham or more or less, and if I ratify the sale or the lease, the amount I gave will be part of the total price, if I cancel the agreement, then what I gave will be for you without any exchange." (Al-Baji, 1913)

Therefore, the Urboun is a non-refundable sum of money (unlike Hamish al-jiddiyah) fully retained by the bank as collateral to ensure the customer's compliance with his promise to purchase or lease an asset and to guarantee the proper execution of the contract previously established. This sum will be part of the agreed price in case the promise made is fulfilled and the terms of the contract are respected (El Tiby, 2011).

On the subject of the validity of Bai 'al Urboun, three of the four Madahibi ${ }^{1}$ the Hanafi, Maliki and Shafi'i have agreed that it is invalid based on the Quranic verse Surah An-Nisa, Ayat $29^{2}$ (Saniki, nd). It states that it is forbidden to take another's money illegally except in a transaction with mutual agreement, Bai 'al-Urboun falls into this category as the seller take the Urboun without any compensation (Al-Qortobi, 1964). They also, sustained their point of view by the hadith ${ }^{3}$ reporting that the prophet (PBUH) banned Bai 'al-Urboun (Imam Malik, 1985) (Abu Daoud, 2009) (Ibn Hanbal, nd).

Conversely, the Hanbali allows Bai 'al-Urboun arguing that the Hadith used by the other schools as proof is weak (da'if) (Al- Nawawi, nd) (Ibn Qaim, nd). They support their own standpoint by evidence from the story of Nafi' son of 'abd al-Harith, the Khalifa's Omar Ibn al-Khattab agent in Mecca, when he bought from Safouane Ben Omaya a construction on the payment of 4000 dirhams. Provided that if Omar approves the sale, the transaction is conclusive, otherwise Safouan can keep 400 dirhams to himself (Ibn Hijr, 1959) (Al-Baihaqi, 2003).

The use of Urboun, as a precaution in case of an unfulfilled promise, takes place in Ijarah and Murabaha in three situations (BNM,2014) (Wahyudi \& al, 2015):

- When the customer decides not to select the asset already bought by the bank to lease or to buy,

- When he decides not to continue for the entire lease period agreed upon,

- When he is unable or don't want to pay the money owed at its payment date.

\footnotetext{
${ }_{1}^{1}$ Al Madahib are scientific schools that try to understand and explain religious texts to develop jurisprudential rules that Muslims need in their lives to know the appropriate decision to take in a given situation.

${ }_{2}$ «O you who have believed, do not consume one another's wealth unjustly but only [in lawful] business by mutual consent » see https://quran.com/4/29

${ }^{3}$ From Amr son of Shu'aib, from his father, from his grandfather; That the prophet (peace and blessings be upon him) forbade the sale of Urboun. Nayl al-awtar $v \quad 5 \quad$ p 182 see http://shamela.ws/browse.php/book-9242\#page-1741
} 
The IFI, thusly, uses the Urboun to compensate for the damage it has suffered.

In regard to Istisna', Urboun is used firstly, as a protection against the market risk (particularly the risk of price variation). This risk takes place when the costumer terminates the contract, the bank is forced to continue making the merchandise and sell it to another person at a price that may be lower than the one agreed upon initially. Secondly, it is used against credit risk that occurs in case the customer is unable to honor his financial commitments, such as deferred instalments or billing payments. Whatever loss generated in these situations, it can be offset by the amount of Urboun (Wahyudi \& al, 2015).

\section{Rahn (Collaterals)}

The Rahn is a commitment between a debtor (Rahin) and a creditor (Murtahin) whereby an asset (Marhun), that has a financial value, is pledged as safety measure to provide insurance that the debtor's obligations towards the creditor are fulfilled (BNM, 2015) (Sabiq, 1983).

In the Islamic finance industry, Faleel (2012) argues that a client can offer a pledge or guarantee via a Rahn contract in order to obtain a financial liability; to mitigate credit risk, IFI use the Rahn contract.

Regarding its validity, the Rahn is permissible by the four Madahib. Their consensus is proved by the explicit texts in the Qur'an and Sunnah, such as the Ayah 283 Surah Al-Baqarah which says that if a traveling person needed to borrow some money and there was no clerk or someone else to bear witness, he can use as substitute a Rahn received by the creditor (Ibn Kathir, 1999) and also from what was narrated that the Messenger of Allah (PBUH) had died and his shield was mortgaged to a Jew for thirty Sa' ${ }^{4}$ of barley (Al-Bukhari, 2001).

The Rahn can be utilized in different products, such as Ijarah, Murabaha, Qard Hassan, Salam and Istisna'. In regards to Ijarah, besides the market risk, Rahn can be applied for two purposes (BNM, 2014):

- To ensure that the customer pay his rent on the agreed date without any delay,

- to protect itself against major damages caused trough the customer's misuse or negligence, since the leased asset remains all along in the bank's property.

By the same token, the Rahn is also used in Murabaha as a protection from the risk of a delayed payment or non-payment of the selling price. It forces the client to respect his commitments and to preserve the bank's interests.

Concerning Salam, since the price of the goods is given at the beginning of the transaction, the debtor may choose not to fulfil his obligation just after receiving the money from the bank. In that case, the latter may request a Rahn, proceed with its liquidation, and use it to make up for the losses suffered. ( Wahyudi \& al, 2015)

\footnotetext{
${ }^{4} \mathrm{~A}$ measure used to weigh cereals and other things (see K.al-sarhid, Sa' al-nabawi), it's equal to 2.97 Kg (see A. moarak, al-mizan, p 55)
} 
As for Istisna', in addition to market risk, the IFI are exposed to the risk of losing their invested capital in case the products in the making process are not delivered, not delivered on time, or not delivered according to the specifications set at the time of signing the contract. The IFI can use Rahn as a guarantee that the contract is well executed and make sure that the goods are delivered at the agreed time and according to the agreed specifications. (Archer \& Rifaat, 2013) Qard Hassan, literally meaning "gratis loan", is a loan granted by an IFI with the borrower's commitment to return the tantamount of the money borrowed (Al-Kassani, 2003). The banks reward is of a religious nature. Nevertheless, Islam allows that the lender demands guarantees from the debtor, hence the use of Rahn, which following a misjudgement of the ability of the debtor to pay, can be used by the bank to recover the money lent. The only requirement is that the total value of the Marhun must be fairly equal to the amount lent by the bank to the debtor (Wahyudi \& al, 2015).

\section{Al-Kafala (Third-Party Guarantee)}

As part of a financial transaction, a third party under the kafala contract becomes a guarantor for the payment of a debt or the fulfilment of an obligation if it is not paid or fulfilled by the person initially responsible for ( Iqbal \& Mirakhor, 2011). In other words, a person becomes obliged to fulfil the responsibility of someone else.

There are four types of Kafala namely: Kafala bi-Nafs, Kafala bi-mal, Kafala bi-alain or bi-al-taslim and Kafala bi-al-darak (Aazam, 1976) that allow an institution to take multiple financial and performance guarantees.

- Kafala bi Al-Nafs (personal guarantee): Muslim jurisprudence allows this kind of guarantee where the liability is related to financial matters. It means that a third party (al-kafil) undertakes to bring the debtor (al-makfoul) to the creditor (al-makfoul lah) so he can honor his obligations.

- Kafala bi Al-Mal (financial guarantee): the guarantor in this type of kafala is liable for the undertaken financial claim to ensure the payment of the debt.

- Kafala bi Al-'Ain or bi al-Taslim (Delivery Guarantee): it is the commitment to guarantee the delivery of a property to its owner.

- Kafala bi Al-Darak: it is a guarantee of the interest of the buyer. It stipulates that the seller must refund the money paid by the buyer if it turns out that the object of the transaction is not his property or does not comply with the specifications agreed upon in the contract.

The majority of scholars agree on the legitimacy of kafala, citing as evidence the Ayat ${ }^{5} 72$ surah Yusuf, which indicates that both type of Kafala, kafala bi al-Nafs and kafala bi al-Mal, were valid in the law back then (Al-Charbini, 1868), and the hadith ${ }^{6}$ stating that prophet (PBUH)

\footnotetext{
${ }^{5}$ They said, "We are missing the king's tumbler; and whoever comes up with it shall have a camel's burden; and for that I am a (sure) guarantor." See https:/quran.com/12/72?translations=17,18,19,20,21,22,43, 84,85,95,101

${ }^{6}$ From Abi Omamah, that the prophet (PBUH) said: "The borrowed is to be returned, and the guarantor is responsible, and the debt is to be repaid.". see https://sunnah.com/tirmidhi/14
} 
ruled that the guarantor is bound to pay what he had guaranteed which gives proof that the Kafala is legitimate (Al-Mubarakafori, nd) (Al-Tirmidhi, 1996).

Whilst the discussion in the preceding paragraph has enabled the comprehension of the Kafala's categories, we're going to try in the next to explain its use in the Islamic financing products. Kafala in Murabaha is used to address the problem of counterparty risk where the bank is forced to sell the goods purchased in the market if the customer refuses to buy them. The IFI may use Kafala bi Al-Nafs by requiring a third party who guarantees to bring the issuer of the purchase order to honor his obligations, or Kafala bi Al-Mal by demanding a third party to guarantee the payment of the amount owed by the debtor (Wahyudi \& al, 2015).

An equally significant use of Kafala bi Al-Nafs and Kafala bi al-mal is possible in the Qard Hassan contract, by forcing the customer to come forward to pay his debt or by forcing the guarantor to pay the owed amount (Wahyudi \& al, 2015).

As for Ijarah, in order to ensure the payment of the lease fee, the IFI may use Kafala bi Al-Nafs or Kafala bi Al-Mal (BNM, 2014), and may use Kafala bi Al-'Ain to take back the asset leased in case the lessee does not wish to continue for the entire prearranged period.

The goods being paid in advance in Salam, the customer may choose to not fulfil his obligation just after receiving the money. Thereby, the IFI through Kafala bi Al-Mal and kafala bi AlDarak have the opportunity to recover its invested capital and can contain whatever loss it has suffered (Wahyudi \& al, 2015).

Apropos of Istisna', since the deal in this type of contract is made without inspection of the traded goods (without seeing them), there is the risk that they will not be manufactured according to the specifications initially indicated and planned; the IFI can solve this problem by opting for Kafala bi al-darak which allows the recovery of the money advanced to the manufacturer.

\section{Al-Khiyarat}

The origin of the word Khiyar comes from the word " Ikhtyar " which literally means " selection " (Al-Hamiri, 1999). It implies the ability to choose the best of two options (Al-Jaziri, 2003). It was primarily designed to meet the interests of business transactions in Islamic law, including the assurance of both parties' benefits and wishes and their protection from any danger that may affect their business in the future (Murshidi \& al, 2013).

Abo ghudda defines al-khiyar as the right of one of the contractors to terminate the contract following the appearance of a legitimate reason (something that does not comply with Sharia directives) or due to non-compliance with one of the contract terms (Abo ghudda, 1985). Fiqh specialists have divided Al-Khiyarat into several categories for managing different litigation situations. We are going to present a list of definitions and some explanations for each one of them with the intention of showing their usefulness in risk management. 


\subsection{Khiyar al-Majlis}

The expression Khiyar al-Majlis consists of two words, the first " Khiyar " was previously explained, the second "Majlis " which means, according to the Journal of the Judicial Verdicts (JJV) Art. 181, the place where the contract parties meet for the completion of a business transaction. The contractors, through Khiyar al-Majlis, have thus the choice to cancel or confirm a transaction as long as they are together in place of the contract signing ceremony before they parted physically. Otherwise, the contract is binding and neither of them has the right to terminate it (Murshidi \& al, 2013).

However, the application of Khiyar al-majlis varies according to the four Madahib. The Shafi'i and Hanbali assert the validity of this type of option; they are of the opinion that the buyer and the seller retain the option to cancel the contract as long as they have not left the contractual session (Al-khatabi, 1932) (Al-Ramly, 1984) (Al-Qaliyubi, 2003). Whereas, for the Hanafi and the Maliki, a sale is concluded and commits both parties on the expression of the offer and the acceptance. Therefore, there is no option of termination (Ibn Jozaii, nd) (Ibn Hijr, 1959) (Al-Balkhi, 2000) (Al-Marghinani, 1997).

\subsection{Khiyar al-Shart}

The word "Shart " meaning in Arabic " condition" when paired with Khiyar offers to both contractors the right to cancel or confirm a transaction for a predefined period agreed between the two parties (Ibn 'Abidin, 2003). To put it another way, Khiyar al-Shart gives the contracting parties, at the time of conclusion of the contract, the possibility to put a condition of choice that allows them to cancel the contract within a specified period (Mar'i, 1973). This implies that they have a certain amount of time to reassess the benefits and the costs involved before taking the final decision (Obaidullah, 1998).

The four Madahib have the same take on the legitimacy of Khiyar al-Shart; for all of them its permissible. They support their argument by the Hadith ${ }^{7}$ in which the prophet (PBUH) ruled that a sell between two contractors is not binding if one or both of them stipulate the condition of choice for a definite period.

The only disagreement they have is on the duration of the Khiyar. For the Hanafi and the Shafi'i, it must not exceed three days (Al-Nawawi, nd) while for the Maliki and the Hanbali the duration varies according to what is needed (Ibn Qodama , 1997) (Ibn Rochd, 1994).

It can be used in binding contracts such as Murabaha and Ijarah (Daoud, 2011) to mitigate different risk, namely:

- Counterparty risk: in case the costumer does not keep his promise to purchase or lease the asset,

\footnotetext{
${ }^{7}$ Narrated the son of Omar, the prophet (PBUH) said: "No deal is settled and finalized unless the buyer and the seller separate, except if the deal is optional (whereby the validity of the bargain depends on the stipulations agreed upon). Sahih al-Bukhari, vol3 p 64 hadith 2111 see https://sunnah.com/bukhari
} 
- Mark-up risk: which takes place in case there is a difference between the prices initially agreed upon and the new ones, if the bank has to resell the asset or find another lessee,

- Liquidity risk: in the form of non-compliance with the payment deadlines,

- The risk of increased storage costs: it occurs when the bank has to keep the property in its possession while waiting to find another client instead of the original one.

By specifying a duration that allows it to terminate the initial contract and find another potential customer to make a new transaction, the IFI can avoid such risks.

\subsection{Khiyar al-`Aib}

In order to comprehend the term Khiyar al-'Aib, it appears necessary to explain the word " 'Aib", which translates to the word " default ". It was defined by Ibn Rochd as all that is missing from the natural or legal creation of a product and has the direct effect of reducing its value and consequently reducing its selling price (Ibn Rochd, 1994) (Al-Othaimin, 2002).

According to the article 336 of the JJV, any buyer in Islamic law has an implicit guarantee against latent defects in purchased goods. This comes from the fact that the fundamental principle in any transaction or affair between two people in Islam is the prohibition of any kind of cheating or deception.

Hence Khiyar al-' Aib is a legal right, that is to say, there is no need to stipulate a special clause or option in the contract to benefit from it (Rayner, 1991). It allows the buyer to terminate the contract if he discovers a defect in the asset object of the transaction that the seller was unaware of at the time of settling the deal (Al-zohaili, 1985).

There is a consensus among the scholars about the validity of Khiyar al-'Aib that has been based on evidence from the Qur' an Sourat Nisaa Ayah ${ }^{8}$ 29. It implies that the concealment of defects in a sale is contrary to the condition of mutual consent between the contractors, and that an ambiguous contract is a trade without compromise. Also, from the Sunna, using the hadith ${ }^{9}$ stating that the integrity of the products object of the transaction is a prerequisite, and if there is a default, it must be pointed by the seller (Ibn Majah, nd).

This type of option can be used in the various Islamic contracts that implies the purchase or the sale of non-inspected goods at the time of the conclusion of the contract (Kamal, 2013), like Istisna 'and Salam. In Istisna' and Salam, the bank may experience a quality risk if the subcontractor or the seller does not meet the specifications indicated and agreed upon in the contract. In other words, it faces the possibility of substandard delivered products; Khiyar al-

\footnotetext{
8 " but only [in lawful] business by mutual consent » see https://quran.com/4/29

${ }^{9}$ It was narrated that 'Uqbah bin 'Amir said: "I heard the Messenger of Allah (PBUH) say: 'The Muslim is the brother of another Muslim, and it is not permissible for a Muslim to sell his brother goods in which there is a defect, without pointing that out to him."' Sunan Ibn Majah, v2 p 755 hadith 2246 see https://sunnah.com/ibnmajah/12
} 
'Aib can protect the bank against this risk by allowing the termination of the contract after inspecting the products in question.

\subsection{Khiyar Al-Ro'yah:}

The word " Ro'yah" in Arabic means " seeing through the eye ". It consists in our context to look at the object of the transaction, to ensure the perception of its nature, and the inspection of its physical features (Al-Razzi, 1975).

Khiyar al-Ro'yah therefore, is a right given to the buyer to confirm a purchase agreement or to reject it after having seen the object of the transaction, if he had not seen it in the beginning (Ibn Nujaym, 2002). AL-Sanhouri (1998) elucidates that the foundation of Khiyar al-Ro'yah is the buyer's mistake in the perception of the nature or the properties of something he has never seen.

The majority of scholars agrees on the validity of this Khiyar supporting their standpoint by the hadith (Al-Sakhaoui, 1985) which states that if someone purchases something he hadn't seen, he has the choice to revoke the deal when he sees it. In contrast, only the Shafi'I, who considers the sale of something that is not present at the place of the contract, is invalid for the simple reason that there are unknown risks, that qualifies Khiyar al-Ro'yah as invalid (Ibn Humam, 2003). It can be used in the same way as Khiyar al-'Aib, to protect the bank against the risk of substandard delivered products by allowing the termination of the contract after inspecting them at the time of delivery.

\subsection{Khiyar Al-Tadliss}

The word " Tadliss " indicates any kind of fraud enabling the seller to conceal the defects of a product or give it a false presentation in order to make it more attractive with the malicious intention to increase its value and its price (Al-Razzi, 1975). Accordingly, Khiyar Al-Tadliss is the right that allows the buyer to cancel a transaction tainted with this type of fraud (Sabiq, 1983).

The four Madahib unanimously agreed that this Khiyar is valid, arguing that Tadliss is Haram; it involves cheating, lies and deception using as evidence the hadith ${ }^{10}$ in which the prophet (PBUH) forbid dishonesty and using another ${ }^{11}$ in which the prophet gave permission to use al-Khiyar in case there is Tadliss (Ibn Malik, 2004).

\footnotetext{
${ }^{10}$ It is narrated on the authority of Abu Huraira that the Messenger of Allah ( (c) observed: He who took up arms against us is not of us and he who acted dishonestly towards us is not of us. (M.alnaissabouri, Sahih muslim, Dar ihia' al-thorat al-'arabi,Vol 1 p 99 hadith 101/43) See https://sunnah.com/muslim/1

${ }^{11}$ Malik related to me from Abu'z-Zinad from al-Araj from Abu Hurayra that the Messenger of Allah, may Allah bless him and grant him peace, said, "Do not go out to meet the caravans for trade, do not bid against each other, outbidding in order to raise the price, and a townsman must not buy on behalf of a man of the desert, and do not tie up the udders of camels and sheep so that they appear to have a lot of milk, for a person who buys them after that has two recourses open to him after he milks them. If
} 
This option can be used in all types of contract that involve the purchase of goods manufactured or produced according to particular specifications such as Istisna' and Salam. Since in these two contracts the agreement is made on the basis of the promises of the manufacturer (Istisna ') or the seller (Salam) which increases the possibility of fraud activities, Khiyar Al-Tadliss gives the bank the possibility to mitigate this risk by allowing the termination of the contract.

\subsection{Khiyar al-Naqd}

It is a right granting the seller the power to terminate a contract within a period of time, specified at the beginning of the transaction, if the buyer does not pay the amount due before the end of that period (Ibn 'Abidin, 2003) (Khan, 2003)

In its article number 313, JJV explains that: "when two parties agree to make a transaction whereby the buyer agrees to pay the purchase price at a specified time, if he does not pay it the transaction is cancelled, this is called Khiyar al-Naqd".

Khiyar al-Naqd is a particular case of Khiyar al-Shart, since the condition (Shart) here is the payment of the sum owed by the client. Al-zohaili (1985) emphasizes that the only difference is that in Khiyar al-Shart once the validity period of the Khiyar is finished without cancellation, the contract becomes binding and the exchange must take place. Whereas in Khiyar al-Naqd, if the period is expired and the buyer did not pay the amount due, the transaction is annulled (Al-Zohaili, 1985).

The legitimacy of this Khiyar create a disagreement between the scholars. The Hanbali, the Hanafi, and the Maliki (Al-Dasouqi, nd) (Al- Nawawi, nd) ruled that it is valid relaying on alQiyas $^{12}$ as in the case of Khiyar al-Shart (Ibn Qodama) (Al-Kassani, 2003). While the Chafi'i consider it invalid (Najdat, 2013)

This Khiyar can be used in several ways by the IFI (Al-'Ali, 2008) (Dubai Islamic bank, nd) (Chabir, 1993):

- In Murabaha and Ijarah: as we explained before the bank is not the natural owner of the asset in these contracts. It has to buy it from another supplier. In order to protect itself from counterparty risk, the bank can use Khiyar al-Naqd in the contract with the supplier, so that if the customer does not keep his promise, the bank can cancel the deal with the supplier by not paying the amount due.

- As protection from the customer's procrastination in the payment of the purchase price or rent: the bank can use Khiyar al-Naqd to rescind the contract in order to find another potential

\footnotetext{
he is pleased with them, he keeps them and if he is displeased with them, he can return them along with a Sa' of dates." See https://sunnah.com/malik/31

${ }_{12}$ Qiyās (Arabic: قياس) is the process of deductive analogy in which the teachings of the Hadith are compared and contrasted with those of the Qur'an, in order to apply a known injunction (nass) to a new circumstance and create a new injunction. See https:/en.wikipedia.org/wiki/Qiyas
} 
customer and eventually protect itself from the risks generated in such situation like market risk and increased storage costs (Najdat, 2013).

- To hedge itself from liquidity risk: by requiring the payment of the amounts due on certain maturities, the IFI ensures liquidity inflows within defined timeframes through Khiyar alNaqd. Hence, it has sufficient liquidity to cover its expenses and to cope with unexpected cash outflows.

- To protect itself from legal risks: in fact, to terminate a contract without the client's agreement, the bank will have to resort to the court. This is not in the bank's advantage because the legal systems of most countries with dual banking systems do not have laws that support the unique features of IFI. Also, the lack of standardized contracts and the absence of Islamic courts to help resolve the problems associated with the applicability of these contracts increases the legal risks. (Habib \& Khan, 2001).

\subsection{Khiyar al-Ghabn}

The word " Ghabn " in a purchase or a sale transaction means deception. It occurs if the prices of the goods bought or sold are higher or lower than the usual ones (the prices known in the market) (Ibn Mandour, nd) (Al-Fayuomi, 1987). Khiyar al-Ghabn is, therefore, the right to terminate a contract following the discovery of a blatant cheating in the prices (Al-Hassoun, 2002).

The Fiqh scholars have divided Al-Ghabn into two categories (Ibn 'Abidin, 2003) (Al-Zohaili, 1985):

- Ghabn Yassir (minimum and tolerable): it is all customary difference among a market's economic agents, between the price at which a good is sold or purchased and the common price in the market, estimated at 10 percent. By way of example, if a good is sold or bought for 10 currency units, while its real price is 8 or 9 , the difference is minimal and it is called tolerable Ghabn. Unanimously, the scholars agree that this type of Ghabn does not give the right to use Khiyar al-Ghabn.

- Ghabn Fahich (excessive): It is any unusual and unjustified difference between the prices. For this kind of Ghabn, the scholars, in particular the Hanafi, have linked the termination of the contract with the existence of a misleading presentation (Taghrir). Otherwise, neither of the contractors have the right to rescind it (JJV, Art 356-357). The Hanbali says that the excessive Ghabn does influence the contract whether there is a misleading presentation or not. That being the case, the use of Khiyar al-Ghabn is permissible for them.

The Shafi'i, on the other hand, states that Ghabn Fahich does not affect the validity of the transaction in both cases, for the simple reason that the deception (Taghrir) happened because of the person's negligence. Forasmuch as if he had consulted an expert, he wouldn't have been deceived. 


\subsection{Khiyar al-khiyanah (betrayal option)}

The word " khiyanah " means in Arabic disloyalty, breach of trust, or deception (Ibn Mandour, nd). Wherefore, Khiyar al-khiyanah is the power to choose between two options in case of presence of deliberate and premeditated deceit.

Fiqh scholars have different points of view concerning this Khiyar; for the Hanafi and the Maliki, the buyer in case of Khiyanah can choose between the two options mentioned above while for the Chafi'i and the Hanbali, the buyer cannot terminate the contract. The only choice he has is to reduce the price of the goods as it was explained before (Al-Zohaili, 1985).

It is generally used in Boyo' Al-Amana (Murabaha, Tawlia, Ichrak and Mowada'a), where the price is equal to the capital (initial price), increased or decreased. It is called Boyo' Al-Amana (sale of trust or honesty) because the transaction is based on trust. The buyer considers what the seller tells him to be true and buy based on his words.

If the seller deceives the buyer by raising the purchase price with the intention of increasing his profit, the latter is entitled to use Khiyar al-khiyanah that allows him to choose between terminating the contract or reducing the purchase price by the equivalent of the additional amount (Al-Zohaili, 1985). The IFI could use in the same way Khiyar al-Khiyanah to protect its interests if the condition aforementioned occurred.

\subsection{Khiyar Tafarruq al-Safqa}

The scholars call Tafaruq al-Safqa any situation in which the contract's validity does not relate to all the goods included therein so that a single transaction can be separated (Ministry of Awqaf \& Islamic Affairs Kuwait, 1983). This takes place in two scenarios:

- when the buyer discovers that the seller owns only a part of the asset object of the transaction (he is not the sole owner). We are talking about the concept of Al-Istihqaq al-joz'i (partial ownership).

- When he discovers that this asset is partially damaged "the concept of Al-halak al-joz'I" (partial damage) (Al-Zohaili, 1985).

Khiyar Tafaruq al-Safqa is the right granted to the buyer to terminate the contract and retrieve the money he gave or continue the transaction and recover the rest after deducting the damages, if one of the two situations explained above occurred (Al-Zohaili, 1985).

There is a difference of opinion among the scholars on the subject of Khiyar Tafaruq al-Safqa (Al-Zohaili, 1985):

In the case of Halak Joz'i: for the Hanafi school, if the damages are caused by the seller or a natural reason, the buyer can terminate the contract. If they are caused by a third party, the buyer can choose between the termination or compilation of the deal. The Maliki school, however, ruled that the buyer can choose between these two options, but if he chooses to continue the deal, the purchase price must be revised according to a new contract. 
As for Al-istihqaq al-joz'I: The Shafi'i and Maliki and Hanbali scholars say that the transaction is valid providing that the seller has the full ownership. Otherwise, it is valid in what he owns and invalid in the rest.

The schools of law have considered also another kind of Tafaruq al-Safqa:

The sale of two products one being Halal (licit) the other Haram (illicit) in the same transaction. The Maliki school ruled that the whole transaction is not valid while the Chafi'i and Hanbali say that it is valid in the halal part and invalid in the haram part.

The use of this option appears more beneficial for an IFI in the Salam contract, since this type of contract is generally used in the field of agriculture. Agricultural products are of a perishable nature which increases the possibility of buying damaged goods. Khiyar Tafaruq Al-Safqa allows the bank to protect itself against this type of risk.

\section{Ta'wid (Compensation)}

The word Ta'wid derives originally from the word "'iwad" which means "instead". So, Ta'wid refers to the compensation of something by another (Ibn Mandour, nd). According to the Shariah Advisory Council (SAC) of BNM (2010), Ta'wid refers to the actual losses incurred by the bank in the event of a debtor's refusal or late payment of debt, which are assessed and determined by a third party. Tun (2012) argues that because it is difficult to determine the amount of the actual losses and given the importance of uniformity in the banking industry, the SAC has decided that the losses should be determined by a third party. Ta'wid is therefore a fine agreed upon by the contractors, as an indemnity that may be claimed by the creditor to cover his losses when the debtor do not pay or is late in paying his debt (Yaakub \& al, 2013).

In regards to the validity of Ta'wid, the scholars have used as evidence Surah Al-Baqarah Ayat ${ }^{13} 194$ which was interpreted as a permission to take compensation (Al-Qortobi, nd). Also, the famous story of Solomon and David ( Surah Al-Anbya Ayat 78 ${ }^{14}$ ), when someone's sheep grazed in another's planted land ruining it, they asked David and Solomon to be the judges in order to solve their dispute, and they ruled that the herd must be given to the land owner as compensation for the damages (Ibn Qaim, 1991).

As for its use by an IFI there is a difference in the scholars' opinions:

The AAOIFI in its Shari'ah Standard, the Majma al-fiqh al-islami (IIFA) of the Organisation of Islamic Cooperation in its Review (6th edition) and the Islamic Fiqh Council of the Muslim World League in its 11th conference recommendations, have ruled that this practice is not

\footnotetext{
13 [Fighting in] the sacred month is for [aggression committed in] the sacred month, and for [all] violations is legal retribution. So, whoever has assaulted you, then assault him in the same way that he has assaulted you. And fear Allah and know that Allah is with those who fear Him. See https://quran.com/2/194-204?translations=20

${ }^{14}$ And [mention] David and Solomon, when they judged concerning the field - when the sheep of a people overran it [at night], and We were witness to their judgement. See https://quran.com/21/78
} 
permitted in any case. They argue that this practice is nothing but prohibited Riba and therefore IFIs cannot in any way use it.

However, some Contemporary Islamic scholars such as Al-Darir. M.A (1985), Ibno Manii'. A (1989), Al-Zarqaa. M (1996) and Al-Jalaf (1996), have stated that a compensation shall be paid to the IFI for the damage caused as a result of a delayed payment. Provided that the damages are real, substantial and that the agent has the ability to honor his obligations but chooses to procrastinates.

They use as an argument the fact that by procrastinating on purpose, the agent causes damages to the IFI and commits an injustice towards it (he is considered as a usurper). This kind of practice is prohibited as it is explained in the Surah Al-Furqan Ayat $19{ }^{15}$ and the Hadith Qudsi ${ }^{16}$.

Although they all agree about the legitimacy of this practice, they differ on the nature and the amount of the compensation:

Ibno Manii'. A (1989) argue that if the amount paid is considered as a dissuasive act (punishment for delaying the payment on purpose) and it's not equal to the amount of the losses, then it's permitted. On the other hand, if it is equal to the losses and it's considered solely as a compensation, then it's prohibited.

Al-Zarqaa.M (1996) and Al-Darir (1985), they both agree that it can be considered as indemnification. However, Al-Zarqaa specifies that the mount paid must and can only be estimated by a judicature. While Al-Darir emphasizes that the amount to be paid can be agreed upon earlier between the IFI and the agent.

As for the amount paid, Al-Darir (1985) affirm that it is estimated according to the profit that the IFI has gained for an equal amount of money during the time of delay. Whereas Al-Jalaf (1996), say that the amount paid as indemnification must be equal to what the agent has gained by doing business with the money owed, not to the damages suffered by the IFI.

Regarding its use in Islamic financing products, the contracting parties may agree to include a clause in the Ijarah or Murabaha contract stipulating late payment charges. Ta'wid, in this case, is considered an indemnity for the actual loss borne by the IFI; it can be counted as income (BNM, 2014).

\section{Gharamah (Penalty)}

According to the Cairo Arabic Language Academy, al-Gharamah is a pecuniary sanction that aims to inculcate discipline, as well as to impose compensation between individuals. In our

\footnotetext{
15 " And whoever commits injustice among you - We will make him taste a great punishment." See: https://quran.com/25

${ }^{16}$ On the authority of Abu Dharr al-Ghifari (may Allah be pleased with him) from the Prophet (데 (c) is that among the sayings he relates from his Lord (may He be glorified) is that He said: "O My servants, I have forbidden oppression for Myself and have made it forbidden amongst you, so do not oppress one another....". see: https://sunnah.com/qudsi40/17
} 
study context, Gharamah is a penalty imposed by the IFI on the client for delayed payment of his debt, sans the need to prove the actual losses (Yaakub, 2014).

In regards to the use of Gharamah in Islamic products, contracting parties in Ijarah or Murabaha may agree to include a clause stipulating late payment charges, but unlike Ta'wid, the money received through Gharamah should not be counted as income; it should be channelled to charities (BNM, 2014)

As for Salam, the unique nature of this contract exposes the IFI to multiple risks as we have explained earlier, such as the risk of undelivered goods. A penalty (Gharamah) imposed by the competent regulatory authorities, may be put in place to prevent this kind of practice (Wahyudi \& al, 2015).

\section{Conclusion}

In their evolutionary path, IFI do not go without encountering a lot of difficulties and problems. Risk management stands as one of the most difficult to overcome due to their unique operating systems and the unique financial instruments they use.

In this modest work, we tried to highlight the efforts made by these institutions and to reveal the methods they have adopted to provide the appropriate solutions to the different problematic situations. It is the application of certain principles of the Sharia, from Quran and Sunna, as tools of risk management. Indeed, by reviewing these principles, we found that Islamic finance has derived a range of risk management tools that they have made adaptable and applicable in different circumstances and for different banking products.

However, the lack of harmonization in Sharia interpretations represent a problem that requires the control of regulatory authorities, such as the Sharia Councils, to ensure a valid and consistent application of these tools.

Finally, and to make the consultation of these applications adopted by IFI, we have developed a cross-tabulation that presents the various tools of risk management, the risks against which they are used and the different instruments in which they are used. 


\begin{tabular}{|c|c|c|c|c|c|c|}
\hline \multirow{2}{*}{$\begin{array}{l}\text { Risk management } \\
\text { tools }\end{array}$} & \multirow[b]{2}{*}{ Type of risk } & \multicolumn{5}{|c|}{ Financing Instruments } \\
\hline & & $\begin{array}{l}\text { Mourab } \\
\text { aha }\end{array}$ & Salam & Istisna' & $\begin{array}{l}\text { Qard } \\
\text { Hassan }\end{array}$ & Ijarah \\
\hline \multirow{3}{*}{ Hamish jiddiyah } & Counterparty risk & & & & & \\
\hline & Market risk & & & & & \\
\hline & $\begin{array}{l}\text { Increased storage } \\
\text { costs risk }\end{array}$ & & & & & \\
\hline \multirow{4}{*}{ Urboun } & Counterparty risk & & & & & \\
\hline & Market risk & & & & & \\
\hline & $\begin{array}{l}\text { Increased storage } \\
\text { costs risk }\end{array}$ & & & & & \\
\hline & Credit risk & & & & & \\
\hline \multirow{6}{*}{ Rahn } & Counterparty risk & & & & & \\
\hline & $\begin{array}{l}\text { Risk of losses on } \\
\text { damaged goods }\end{array}$ & & & & & \\
\hline & Market risk & & & & & \\
\hline & $\begin{array}{l}\text { Increased storage } \\
\text { costs risk }\end{array}$ & & & & & \\
\hline & Credit risk & & & & & \\
\hline & Operational risk & & & & & \\
\hline \multirow{2}{*}{ Kafala bi-Nafs } & Counterparty risk & & & & & \\
\hline & Market risk & & & & & \\
\hline \multirow{2}{*}{ Kafala bi al-mal } & Counterparty risk & & & & & \\
\hline & Lega risk & & & & & \\
\hline Kafala bi al-'ain & $\begin{array}{l}\text { Risk of Losing } \\
\text { property }\end{array}$ & & & & & \\
\hline Kafala bi al-darak & Counterparty risk & & & & & \\
\hline Khiyar al-Majlis & Counterparty risk & & & & & \\
\hline \multirow{4}{*}{ Khiyar al-Naqd } & Counterparty risk & & & & & \\
\hline & Liquidity risk & & & & & \\
\hline & Market risk & & & & & \\
\hline & Legal risk & & & & & \\
\hline Khiyar al-Ro'yah & Counterparty risk & & & & & \\
\hline Khiyar al-‘aib & Counterparty risk & & & & & \\
\hline Khiyar al-Tadliss & Risk of loss on fraud & & & & & \\
\hline Khiyar al-Khiyanah & Risk of loss on fraud & & & & & \\
\hline \multirow{3}{*}{ Khiyar al-Shart } & Market risk & & & & & \\
\hline & Liquidity risk & & & & & \\
\hline & $\begin{array}{l}\text { Increased storage } \\
\text { costs risk }\end{array}$ & & & & & \\
\hline $\begin{array}{l}\text { Khiyar Tafaruq al- } \\
\text { Safqa }\end{array}$ & $\begin{array}{l}\text { Risk of buying } \\
\text { damaged goods }\end{array}$ & & & & & \\
\hline Ta'wid & Credit risk & & & & & \\
\hline \multirow{2}{*}{ Gharamah } & Counterparty risk & & & & & \\
\hline & Credit risk & & & & & \\
\hline
\end{tabular}




\section{References}

Aazam. A, 1976, « Nadariyat al-aqd wa al-kafala »,

Abo ghidda. A, 1985, «Al-khyar and its effect on contracts »,

Abu Daoud. S, 2009 «Sunan Abu Dawood », $1^{\text {st }}$ edition,

Adnan. O, 2011, “Al-Matl Al-Muharram”, مفهومه، صوره، أسبابه، أضر اره، دراسة فقهية اجنماعية) المطل المحرم وأحكامه), Journal of Sharjah University,

Al-'Ali. S, 2008, « Theory of contract »,

Al- Nawawi. Y, « Al-Majmu' Sharh Al-Muhadhdhab », Dar al-fikr,

Al-Baihaqi. A,2003, « Sonan Al-Baihaqi », Dar al-Kutub al-'Ilmiyyah,

Al-Baji.S, 1913 « Al-Montaqa Charh Mouatae Imam Dar Al-hijra Malek Abn Anass »,

Al-Balkhi. N, 2000, « Al-Fatawa Al-Hindiyyah »,

Al-Bukhari.M, 2001, « Sahih al-Bukhari »,

Al-Charbini. K. M, 1868 , « Al-Siraj Al-Monir »,

Al-Darir. M.A, 1985, “Agreement on Obliging a Solvent Debtor to Compensate for Damages of Delinquency", Journal of King Abdulaziz University: Islamic Economics,

Al-Dasouqi. M. A, « Hachiat Al-Dasouqi »,

Al-Fayuomi. A, 1987, « Al-Misbah Al-Monir », Lebanon library,

Al-Hamiri. N. B, 1999, « Chamsso Al-'oloum », Dar Al-Fikr,

Al-Hassoun. A, 2002, « Khiyar al-Ghabn in netting agreements », Journal of Arabic Studies,

Al-Jalaf. A.M, 1996, "The accounting approach for Murabaha transactions in Islamic banks", International Institute of Islamic Thought

Al-Jaziri. A, 2003, « Al-Fiqh 'Ala Al-Mazahib Al-arba'a », House of scientific books,

Al-Kassani. A, 2003, « Badai' Al-Sanai' Fi Tartib Al-Chari'», House of scientific books,

Al-Khatabi. A, 1932, « Ma'alim Al-Sunan »,

Al-Marghinani. A, 1997, « Al-Bidayah »,

Al-Mbarkafori. M. A, « Tuhfat Al-Aahodhi »,

Al-Othaimin. M, 2002, " Al-Charh Al-Momti' 'ala Zad al-Mostaqni' »,

Al-Qaliyubi, 2003, « Hachiata Qaliyubi wa ‘Omaira »,

Al-Qortobi. M, « Al-Jami' Li-Ahkam Al-Quoran ' , 1964, dar Al-kotob al-missria,

Al-Ramly. S, 1984, « Nihayat al-Muhtaj », Dar Al-Fikr,

Al-Razzi. M, 1975, « Mokhtar al-Sihah », Dar al-kitab al-'Arabi, 
Al-Sakhaoui.M. S, 1985, « Al-Maqassid Al-Hassanah »,

Al-Sanhori. A, 1998, « Masadir Al-Haq Fi Al-Fiqh Al-Islmai »,

Al-Zarqaa.M, 1996, "On the permissibility of obliging the defaulting debtor to compensate the creditor", حول جواز إلز ام المدين المماطل بتعويض للائن, Journam of economic and Fiqh studies,

Al-Tirmidhi, 1996, « Jami` at-Tirmidhi »,

Al-Zohaili. W, 1985, « Al-fiqh Al-Islami wa adilatoh », Dar al-fikr,

Archer.S,Rifaat.A.A, 2013, « Islamic Finance: The Regulatory Challenge », John Wiley \& Sons, Ayub.M, 2007, «Understanding Islamic Finance », John Wiley \& Sons,

Bank Negara Malaysia, 2014, « Ijarah”, Islamic Banking and Takaful Department »,

Bank Negara Malaysia, 2015, « Rahn (Shariah Requirements and Optional Practices) Exposure Draft », Islamic banking and takaful department,

Chabir. M.O,1993, «Khiyar al-Naqd wa Tatbiqatoh fi Mo'amalat Al-massarif al-Islamia »,

Daoud. A, 2011, «The provisions of the contract in Islamic jurisprudence and civil law»,

Dubai Islamic bank, Journal of Islamic economy, $N^{\circ} 362$,

EL TIBY.M, 2011, « Islamic Banking: How to Manage Risk and Improve Profitability », John Wiley \& Sons,

Faleel. J, 2012, « Islamic Finance for Dummies », John Wiley \& Sons

Habib. A, Khan. T, 2007, « Risk Management in Islamic Banking », Edward Elgar Publishing, Ibn 'Abidin. M. A, 2003 « Radu al-Muhtar ala al-Dur al-Mukhtar », House of Book's World, Ibn Hanbal. A, « Mosnad Imam Ahmad »,

Ibn Hijr.A, « Fath Al-bari »,1 ${ }^{\text {st }}$ edition, Dar Al-Kotob Al-Salafia,

Ibn Humam. K, 2003, « Fath Al-qadir », Dar al-Kutub al-'Ilmiyyah,

Ibn Jozaii. M, « Al-Qawanin Al-Fiqhya »,

Ibn Kathir. I, 1999, « Tafsir ibn Kathir », Dar Taiba,

Ibn Majah. M.B, «Sunan Ibn Majah, Dar Thiae Al-Kotob Al-‘arabia,

Ibn Mandour. M, « Lissan Al-'Arab », Dar Sadir

Ibn Manii'. A, 1989, «Matlo Al-Ghani Zolmon, Yohillo 'Irdaho Wa 'Oqobataho”, مطل الغني ظلم Journal of International Islamic Fiqh Academy

Ibn Nujaym. O, 2002, « Al-Nahr al-Fa'iq Sharh Kanz al-Daqaiq », Dar al-Kutub al-'Ilmiyyah, Ibn Qaim Al-jawzia, « Badai' Al-Fawaid », International Islamic Fiqh Academy,

Ibn Qaim Al-jawzia, 1991, "I'lam al-Mouqi'een 'An Rabb al-'Alamen », Dar al-Kutub al'Ilmiyyah, 
Ibn Qodama. A, 1993, « Al-Charh Al-Kabir 'Ala Matni Al-Moqni' », Dar al-kitab al-'arabi,

Ibn Qodama. M. A, 1997, « Al-Moghni », Dar 'Alam al-Kotob,

Ibn Rochd. M. A, 1994, «Bidâyat ul-mudjtahid wa nihâyat ul-Muqtasid »,

Imam Malik. A, 2004, « Al-Muwatta' »,

Iqbal. Z, Mirakhor. A, 2011, «An Introduction to Islamic Finance-Theory and Practice » Second Edition, John Wiley \& Sons,

Journal of the Judicial Verdicts, Art 356,

Kamal. A, 2013, « Khiyar al-'Aib fi al-fiqh al-islami », Journal of Surra Man Raa

Khan. A.M, 2003, «Islamic Economics and Finance: A Glossary » 2nd edition, Routledge,

Kureshi.H, Mukhsia.S.I, Mohsin.H, 2015, « Financial Engineering in Islamic Finance the Way Forward: A Case for Shariah compliant derivatives », partridge,

Mar'i. A. A, 1973, « la résiliation des contrats dans la Charia »,

Masiukiewicz. P, 2017, « Expansion of Islamic Finance in Europe », Journal of Intercultural Management,

Ministry of Awqaf \& Islamic Affairs Kuwait, 1983, « Al-Maouso'a Al-Fiqhia »,

Murshidi \& al, 2013, "Rights of Khiyar (Option) in the Issue of Consumerism in Malaysia », Middle-East Journal of Scientific Research,

Najdat. M, 2013, "Kiyar al-Naqd fi al-fiqh al-Islami », Damascus University Journal of Economic and Legal Sciences

Nestorovic. C, 2013, « What is the Future of Islamic Finance? », Islamic Finance News,

Obaidullah. M, 1998, «Financial Engineering with Islamic Options », Islamic Economic Studies,

Rayner. S. E, 1991, «The Theory of Contracts in Islamic Law, Springer,

Sabiq. S, 1983, « Fiqh Al-Sunna », Al-fath lili'lam al-'Arabi,

Saniki. Z, « Asna Al-Matalib Fi Charh Rawd Al-Talib »,

Wahyudi.I, Rosmanita.F, Prasetyo.M, Surya Putri.N, 2015, «Risk Management for Islamic Banks Recent Developments from Asia and the Middle East », John Wiley \& Sons

Yaakub \& al, 2013, « Late payment charge in Islamic bank », The 5th International Conference on Financial Criminology (ICFC),

Yaakub. A, 2014, «A Revisit to the Practice of Late Payment Charges by Islamic Banks in Malaysia », Jurnal Pengurusan 42, 